\title{
The Impact of Regulations on Small Firm Characteristics
}

\author{
http://doi.org/10.21272/bel.5(2).66-77.2021
}

\section{Halil D. Kaya, ORCID: https://orcid.org/0000-0002-7535-9857}

Professor of Finance, Department of Accounting and Finance, College of Business and Technology, Northeastern State University, Broken Arrow, OK, USA

\begin{abstract}
Regulations are shown to have a significant impact on entrepreneurial activity, especially on startups by smaller firms. Higher compliance costs are shown to deter small firms entering a new industry. In this study, using state-level regulation data in the U.S., we examine whether different types of regulations (including "health and safety regulations", "employment regulations", "tax code", "licensing regulations", "environmental regulations", and "zoning regulations") in each state deter smaller firms to do business in that state. We also examine whether each type of regulation deters firms to do business in certain industries or to operate in more or fewer states. Besides size, operational area, and industry, we also examine whether each type of regulation deters younger firms to do business in each state. Our results show that "health and safety regulations", "employment regulations", "tax code", "licensing regulations", and "environmental regulations" in a state affect firm size and industry, but do not affect operational area and firm age. In the states with high scores in these areas, there are fewer single-employee firms but more 2-20 employee firms when compared to the other states. Also, in the states with a high score in "environmental regulations", we find fewer firms with 51 to 100 employees when compared to the other states. On the other hand, "zoning regulations" affect firm age and industry, but not operational area and firm size. In the states with high scores in "zoning regulations", we find fewer firms that are established less than a year ago. Finally, in the states with high scores in regulations, generally, we find that more firms are in the "Business" industry and fewer firms are in the "Writing" industry. Overall, we show how each type of regulation deter certain types of firms operating in each state. This is important because if a state wants to attract certain types of firms (i.e., younger, or older firms, larger or smaller firms, or firms in certain industries), the officials in that state need to improve the corresponding regulations first.
\end{abstract}

Keywords: Small Firm, Small Business, Regulations, Entrepreneurship.

JEL Classification: L26; L25; G38.

Cite as: Kaya, H.D. (2021). The Impact of Regulations on Small Firm Characteristics. Business Ethics and Leadership, 5(2), 66-77. http://doi.org/10.21272/bel.5(2).66-77.2021.

Received: 17 April $2021 \quad$ Accepted: 01 June $2021 \quad$ Published: 25 June 2021

Copyright: (C) 2021 by the author. Licensee Sumy State University, Ukraine. This article is an open access article distributed under the terms and conditions of the Creative Commons Attribution (CC BY) license (https://creativecommons.org/licenses/by/ 4.0/).

\section{Introduction}

There are two competing theories on the relationship between regulations and entrepreneurship. The public interest model states that regulations are good for society because they help prevent market failures. On the other hand, the public choice model states that regulations deter new entrants in an industry (i.e., reduces competition) and that this is bad for society. According to this model, regulations are supported by the existing firms because they increase the costs of entry and compliance, which in turn discourages new entrants. Most of the previous papers, including Stigler (2021), Peltzman (1976), Djankov et al. (2002), Klapper et al. (2006), Nyström (2008), and others, support the public choice model. Regulations have a bigger impact on smaller firms because larger firms can cover higher compliance costs while smaller firms fail to cope with these costs. This size effect is shown in Klapper et al. (2006), Van Stel, Storey, and Thurik (2007), Helland and Matsuno (2003), and Branstetter et al. (2014), Calcagno and Sobel (2013), and Bailey and Thomas (2017). Calcagno and Sobel (2013) show that regulations force firms to become larger (to cope with the costs). In this study, we look at the size-effect using state-level regulation data in the USA. Our first contribution is to go into more detail and examine whether different types of regulations "health and safety regulations", "employment regulations", "tax code", "licensing regulations", "environmental regulations", or "zoning regulations" help attract (or deter) smaller firms from operating in each state. For example, do smaller firms refrain from doing 
business in a state if that state's employment regulations are unfavorable? Or do they care more about the health and safety regulations, tax code, or licensing regulations? Or maybe small businesses are more worried about environmental regulations or zoning regulations? So, our first contribution is to examine in detail whether different types of regulations in a state affect a small firm's decision to do business in that state.

Besides looking at the size-effect, we also look at firm age, firm industry, and operational area. Does each type of regulation help attract (or deter) younger firms from operating in each state? Do younger firms care more about employment regulations, licensing regulations, or another type of regulation? If a state has unfavorable employment regulations, does this deter younger firms from operating in that state? How about the industryeffect? Do firms in certain industries care more about employment regulations, tax code, or another type of regulation? Also, does each type of regulation attract larger firms with a larger operational area? Therefore, our second contribution is to examine whether different types of regulations in a state attract (or deter) younger firms, firms in certain industries, or firms with a larger operational area into that state. Overall, this paper shows how each type of regulation attracts (or deter) certain types of firms operating in each state. It is important because if a state wants to attract certain types of firms (i.e., younger, or older firms, larger or smaller firms, or firms in certain industries), the officials in that state need to improve the corresponding regulations first. We review the previous literature in Section 2. The data and the methodology are explained in Section 3. The empirical results are presented in Section 4. Section 5 includes our concluding remarks.

\section{Literature Review}

There are two competing theories on the relationship between regulations and entrepreneurship. The first model is the public interest model (Pigou 1938), which states that regulations help maximize public welfare by preventing market failures. The second model, which is called the public choice model, following Tullock (1967) and supported by many papers, including Stigler (2021), Peltzman (1976) states that existing industry participants promote regulations to protect themselves from new entrants. This model assumes that politicians implement these to benefit the existing firms, which would support them in future elections. Several papers empirically examine the relationship between regulations and entrepreneurship. Almost all these papers support the public choice model. The consensus is that regulations tend to have a negative impact on entrepreneurial activity and that smaller firms are affected more. By reducing new competition, regulations may also lead existing producers to become less innovative (Birnbaum, 1984; Thomas, 1990). Djankov et al. (2002) examine 85 countries and show that the countries with stricter entry regulations are more likely to have more corruption.

According to the authors, in these countries, existing producers use politicians to enact stricter entry regulations to protect themselves from new competition. In these countries, there is also a bigger informal economy. When the number of procedures to start a business is relatively high in a country, new entrants are relatively low. Klapper et al. (2006) support this view by showing a negative relationship between entry requirements and the number of new entrants. They also show that if barriers to entry are higher, new entrants tend to be larger (i.e., only larger firms can cover the high costs of entry). The authors also state that higher barriers to entry hurt society by eliminating the competition. Acs et al. (2009) show that more regulation affects entrepreneurial activity negatively. Nyström (2008) supports this by showing that labor, business, and credit regulations affect entrepreneurial activity negatively. Kreft and Sobel (2005) show regulations, taxes, and private property rights as essential determinants of entrepreneurial activity. Van Stel, Storey, and Thurik (2007) find that while administrative considerations are not important for nascent or young businesses, labor market regulations and minimum capital requirements are important. Parker (2007) shows that rules and regulations affect the organizational form of startups. Dreher and Gassebner (2013) show that entrepreneurial activity is negatively affected if the startup process is more complex or larger minimum capital requirements. Sobel et al. (2007) show that both domestic and international restrictions hurt entrepreneurial activity.

Several other papers show a negative relationship between environmental regulations and entrepreneurial activity (see Pashigian, 1984; Brock and Evans, 1989; Dean and Brown, 1995). Helland and Matsuno (2003) find that the compliance costs deter new entrants and help larger firms cover these costs. Branstetter et al. (2014) show that regulatory reforms helped entrepreneurial activity in Portugal, especially among the smaller, weaker firms. Regulations have a bigger impact on smaller firms because larger firms can cover higher compliance costs while smaller firms fail to cope with these costs. This size-effect is shown in many studies besides Klapper et al. (2006), Van Stel, Storey, and Thurik (2007), Helland and Matsuno (2003), and Branstetter et al. (2014). For example, Calcagno and Sobel (2013) show that regulations force firms to become larger (to cope with the costs). Bailey and Thomas (2017) differentiate between different industries and show that highly regulated industries have less entrepreneurial activity and slower employment growth. They also 
show that regulations affect small firms more negatively. Several papers look from a broader perspective and examine how the institutions overall affect entrepreneurial activity. Valdez and Richardson (2013) suggest that a society's normative, cultural-cognitive, and regulative institutions affect entrepreneurial activity. According to Wennekers and Thurik (1999), institutional framework and demographic, technological, and economic forces are essential for the entrepreneurial environment. Culture is important for entrepreneurial activity. Nyström (2008) argues that legal structure, size of the government, property rights, and credit, labor, and business regulations significantly affect entrepreneurial activity. Stephan and Uhlaner (2010) explain that both the existence of opportunities and the quality of formal institutions affect entrepreneurship. Ovaska and Sobel (2005) explain that corruption levels, credit availability, foreign direct investment, contract enforcement, sound monetary policy, and policies supporting economic freedom are important for entrepreneurial activity. Bjornskov and Foss (2008) show that the size of government is negatively correlated with entrepreneurial activity. Some of the previous studies focus on specific countries. For example, Welter (2004) explains that business chambers, business support agencies, and associations should be more accommodative to women entrepreneurs in Germany, business chambers, and associations. Bock (2004) explains that rural development policies mostly support male entrepreneurs in the Netherlands. Bitzenis and Nito (2005) show that, in Albania, several factors, including unfair competition, changes in taxation procedures, lack of financial resources, and problems related to public order, are detrimental to entrepreneurship, while others like bureaucracy and corruption are not.

Bergmann and Sternberg (2007) examine the entrepreneurial activity in Germany and show that the change in the unemployment level in a region affects startup propensity. Aidis et al. (2007) explain that, for Lithuania and Ukraine, besides the formal institutions, the informal institutions like gendered norms and values also restrict women's startup activities and their access to resources. Aidis, Estrin, and Mickiewicz (2008) explain that Russia's business environment favors entrepreneurial insiders rather than entrepreneurial outsiders (i.e., newcomers) regarding new business start-ups. Manolova, Eunni, and Gyoshev (2008) show that the entrepreneurs in Hungary and Latvia were worried about the availability of skills/knowledge needed for entrepreneurship. They show that, in addition to the availability of skills/knowledge, in Bulgaria, the entrepreneurs were unhappy with the laws, government policies, and regulations promoting entrepreneurship, while in Hungary, entrepreneurs were skeptical about societal attitudes toward entrepreneurship. Nawaser et al. (2011) explain that laws, regulations and motivational factors are detrimental to entrepreneurship in Iran. Ghani, Kerr, and O'Connell (2014) find that, in India, entrepreneurial activity depends upon the education level of local people, the quality of the physical infrastructure, and the strictness of labor regulations. García-Posada and Mora-Sanguinetti (2015) find that, in Spain, higher judicial efficacy increases the entry rate of firms, while it does not affect the exit rate. Overall, previous literature generally supports the public choice model, which states that regulations protect existing firms and larger firms while deterring new firm creation or new entrants in an industry. In other words, these studies generally argue that regulations hurt entrepreneurial activity.

\section{Data and Methodology}

In this study, our objective is to see how regulations in a state affects firm characteristics. We examine how different types of regulations including health and safety regulations, employment regulations, tax code, licensing regulations, environmental regulations, and zoning regulations affect the type of firms (i.e., operational area, firm age, firm size, and industry) operating in each state. The variables in this study are:

Healthreg: score on health and safety regulations;

D Employreg: score on employment, labor and hiring regulations as computed by the survey;

$>$ Taxcode: score on tax code and tax-related regulations as computed by the survey;

L Licenreg: score on licensing forms, requirements and fees regulations as computed by the survey;

$>$ Environreg: score on environmental regulations as computed by the survey;

$>$ Zoningreg: score on zoning regulations as computed by the survey.

The scores on healthreg (i.e., "health and safety regulations"), employreg (i.e. "employment, labor and hiring regulations", taxcode (i.e., "tax code and tax-related regulations"), licenreg (i.e. "licensing forms, requirements and fees regulations"), environreg (i.e. "environmental regulations"), and zoningreg (i.e. "zoning regulations") are in the survey dataset. We converted the letter grades of the survey to numbers (A+ is now 12 and $\mathrm{F}$ is now 1). The firm characteristic variables which we will examine are:

\section{Operational area variables:}

Operstates 1: operating in 1 state;

Operstates2-5: operating in 2-5 states; 
Operstate $>5$ : operating in $>5$ states;

Mostlocal: most sales are local (i.e., within 50 miles of the firm).

2. Firm size variables:

Employees1: firm has only 1 employee;

> Employees2-20: firm has 2-20 employees;

$>$ Employees21-50: firm has 21-50 employees;

$>$ Employees51-100: firm has 51-100 employees;

Employees>100: firm has >100 employees.

3. Firm age variables:

Ageofbus $<1$ : firm is established $<1$ year ago;

Ageofbus1-2: firm is established 1-2 years ago;

Ageofbus3-4: firm is established 3-4 years ago;

Ageofbus $>4$ : firm is established $>4$ years ago.

The industry variables "Business", "Writing", etc. are self-explanatory. We first compute the percentage value for each state. For example, in California, if thirty percent of firms operate in only California, then California's "Operstates1" score is 30 (percent). If fifteen percent of firms in California operate in two-five states, then California's "Operstates2-5" score is 15 (percent), etc. When doing the empirical analyses, we will run nonparametric tests that compare "high" and "low" healthreg score states in terms of firm characteristic. To divide between high- and low-overall score states, we use the mean value of healthreg. Then, we do the same for "employreg" score. We will run nonparametric tests that compare "high" and "low" employereg score states in terms of firm characteristic variables. We use the mean value of employreg to separate high- and lowscore states. We follow the same process for the other regulation variables (i.e., "taxcode", "licenreg", environreg" and "zoningreg"). Table 1 shows the summary statistics for our variables.

Table 1. Sample Statistics (\%)

\begin{tabular}{|c|c|c|c|c|c|}
\hline Variable & Mean & Median & Stdev & Min & Max \\
\hline \multicolumn{6}{|c|}{ Panel A. Regulations } \\
\hline Healthreg & 6.95 & 7.00 & 3.49 & 1.00 & 12.00 \\
\hline Employreg & 7.02 & 7.00 & 3.52 & 1.00 & 12.00 \\
\hline Taxcode & 6.95 & 7.00 & 3.51 & 1.00 & 12.00 \\
\hline Licenreg & 7.02 & 7.00 & 3.55 & 1.00 & 12.00 \\
\hline Environreg & 6.93 & 7.00 & 3.53 & 1.00 & 12.00 \\
\hline Zoningreg & 7.00 & 7.00 & 3.46 & 1.00 & 12.00 \\
\hline \multicolumn{6}{|c|}{ Panel B. Operational Area } \\
\hline Operstates1 & 64.77 & 67.07 & 12.83 & 33.33 & 85.39 \\
\hline Operstates2-5 & 27.64 & 26.53 & 13.28 & 8.24 & 66.67 \\
\hline Operstates $>5$ & 7.59 & 7.53 & 2.56 & 0.00 & 15.00 \\
\hline Mostlocal & 87.66 & 88.24 & 6.02 & 65.00 & 100.00 \\
\hline \multicolumn{6}{|l|}{ Panel C. Firm Age } \\
\hline Ageofbus $<1$ & 6.16 & 6.02 & 2.84 & 0.00 & 11.90 \\
\hline Ageofbus1-2 & 17.31 & 16.67 & 5.58 & 5.26 & 35.00 \\
\hline Ageofbus3-4 & 18.06 & 18.63 & 4.26 & 8.70 & 29.03 \\
\hline Ageofbus $>4$ & 58.46 & 57.50 & 7.74 & 45.74 & 84.21 \\
\hline \multicolumn{6}{|l|}{ Panel D. Firm Size } \\
\hline Employees1 & 53.03 & 52.17 & 6.98 & 36.11 & 68.18 \\
\hline Employees2-20 & 45.49 & 45.23 & 6.70 & 31.82 & 63.16 \\
\hline Employees21-50 & 0.87 & 0.77 & 0.90 & 0.00 & 2.94 \\
\hline Employees51-100 & 0.21 & 0.00 & 0.37 & 0.00 & 1.61 \\
\hline Employees $>100$ & 0.40 & 0.00 & 0.90 & 0.00 & 5.00 \\
\hline \multicolumn{6}{|c|}{ Panel E. Firm Industry } \\
\hline Business & 5.59 & 5.32 & 3.00 & 0.00 & 15.00 \\
\hline Care & 4.48 & 3.88 & 3.05 & 0.00 & 17.39 \\
\hline Events & 21.96 & 20.97 & 6.31 & 10.00 & 44.12 \\
\hline Instruction & 7.04 & 7.26 & 3.32 & 0.00 & 15.00 \\
\hline Vehicle & 2.47 & 2.60 & 1.67 & 0.00 & 5.65 \\
\hline Health & 12.94 & 12.30 & 5.35 & 4.35 & 28.57 \\
\hline Home & 35.03 & 35.42 & 5.54 & 21.74 & 45.00 \\
\hline Technology & 9.73 & 9.52 & 4.97 & 0.00 & 30.00 \\
\hline Writing & 0.77 & 0.47 & 0.91 & 0.00 & 3.66 \\
\hline
\end{tabular}

Source: Compiled by the author 


\section{Empirical Results}

Table 2 compares the firm characteristics across the high- and low-"health regulations score" states. The MannWhitney-Wilcoxon test results are in the last column.

Table 2. The Impact of "Health Regulations" on Firm Characteristics

\begin{tabular}{|c|c|c|c|c|c|}
\hline \multirow[b]{2}{*}{ Variable } & \multicolumn{2}{|c|}{ High-Score } & \multicolumn{2}{|c|}{ Low-Score } & \multirow{2}{*}{$\begin{array}{c}\text { Mann-W. } \\
\text { p-value }\end{array}$} \\
\hline & Mean & Med. & Mean & Med. & \\
\hline \multicolumn{6}{|c|}{ Panel A. Operational Area } \\
\hline Operstates1 & 64.69 & 68.48 & 64.89 & 67.05 & 0.4895 \\
\hline Operstates2-5 & 27.17 & 25.00 & 28.23 & 27.11 & 0.3468 \\
\hline Operstates $>5$ & 8.15 & 8.24 & 6.88 & 7.36 & 0.1528 \\
\hline Mostlocal & 87.27 & 88.49 & 88.16 & 87.46 & 0.3371 \\
\hline \multicolumn{6}{|l|}{ Panel B. Firm Age } \\
\hline Ageofbus $<1$ & 6.16 & 6.08 & 6.16 & 5.97 & 0.3565 \\
\hline Ageofbus1-2 & 17.28 & 17.50 & 17.36 & 15.61 & 0.2951 \\
\hline Ageofbus3-4 & 18.27 & 18.46 & 17.81 & 18.93 & 0.4582 \\
\hline Ageofbus $>4$ & 58.30 & 57.14 & 58.67 & 58.41 & 0.2390 \\
\hline \multicolumn{6}{|l|}{ Panel C. Firm Size } \\
\hline Employees1 & 51.20 & 51.61 & 55.37 & 54.27 & $* * 0.0319$ \\
\hline Employees2-20 & 47.29 & 45.67 & 43.19 & 44.15 & $* * 0.0302$ \\
\hline Employees21-50 & 0.89 & 0.77 & 0.85 & 0.70 & 0.4301 \\
\hline Employees51-100 & 0.18 & 0.00 & 0.25 & 0.00 & 0.1384 \\
\hline Employees $>100$ & 0.44 & 0.00 & 0.35 & 0.00 & 0.3270 \\
\hline \multicolumn{6}{|c|}{ Panel D. Firm Industry } \\
\hline Business & 6.11 & 5.71 & 4.92 & 4.91 & $* 0.0670$ \\
\hline Care & 4.08 & 3.83 & 4.99 & 4.35 & 0.4116 \\
\hline Events & 21.79 & 20.97 & 22.18 & 21.44 & 0.3713 \\
\hline Instruction & 6.85 & 6.15 & 7.27 & 7.71 & 0.2642 \\
\hline Vehicle & 2.64 & 2.82 & 2.25 & 2.43 & 0.2186 \\
\hline Health & 12.49 & 11.64 & 13.52 & 13.06 & 0.1930 \\
\hline Home & 35.48 & 35.42 & 34.46 & 35.33 & 0.3371 \\
\hline Technology & 9.94 & 9.52 & 9.47 & 9.20 & 0.4738 \\
\hline Writing & 0.63 & 0.00 & 0.94 & 0.81 & 0.1135 \\
\hline
\end{tabular}

Source: Compiled by the author

First, we compare the high- and low-score states in terms of the operational area variables. We also look at the percentage of firms with ninety percent or more of their sales within fifty miles (i.e., "most local"). We see that the two groups of states are not significantly different from each other regarding the operational area variables. While $64.69 \%$ of the firms in the high-score states operate in a single state, the corresponding percentage is $64.89 \%$ in the low-score states. This difference is insignificant ( $\mathrm{p}=0.4895)$. While $27.17 \%$ of the firms in the high-score states operate in two to five states, the corresponding percentage is $28.23 \%$ in the lowscore states. This difference is also statistically insignificant $(\mathrm{p}=0.3468)$. Finally, while $8.15 \%$ of the firms in the high-score states operate in more than five states, the corresponding percentage is $6.88 \%$ in the low-score states. This difference is also statistically insignificant $(\mathrm{p}=0.1528)$. The result for "most local" is also insignificant. While $87.27 \%$ of the firms in the high-score states have most of their sales within fifty miles, the corresponding percentage is $88.16 \%$ in the low-score states. This difference is also statistically insignificant $(\mathrm{p}=0.3371)$. The result for "firm age" is also insignificant. The mean percentage of firms that are less than one year old, one-to-two years old, three-to-four years old, and more than four years old are $6.16 \%, 17.28 \%$, $18.27 \%$, and $58.30 \%$, respectively, for the high-score states.

The corresponding percentages are $6.16 \%, 17.36 \%, 17.81 \%$, and $58.67 \%$ for the low-score states. None of the differences between the two groups in terms of the age groups is statistically significant. With regard to firm size, we can see that there are fewer firms with a single employee in the high-score states (i.e., 51.20\%) compared to the low-score states (i.e., 55.37\%). This difference is significant $(\mathrm{p}=0.0319)$. Interestingly, we see more firms with 2-20 employees in the high-score states (i.e., 47.29\%) than the low-score states (i.e., 43.19\%). The $\mathrm{p}$-value of the difference is 0.0302 . Therefore, we can conclude that the high-score states, on average, have fewer single-employee firms and more 2-20 employee firms when compared to the low-score states. We do not see any difference between the two groups in terms of the other firm size groups. The two groups are similar concerning the percentage of larger firms. With regard to firm industry, we can see that there is no significant difference between the two groups except for the "Business" industry. There are significantly more firms in the high-score states in the "Business" industry compared to the low-score states. While $6.11 \%$ of the 
firms in the high-score states are in this industry, the corresponding percentage is $4.92 \%$ in the low-score states. This difference is statistically significant $(\mathrm{p}=0.0670)$. Table 3 compares the firm characteristics across the highand low- "employment regulations score" states. We see that none of the operational area variables or the local sales variable (i.e., "most local") is significantly different between the two groups. In other words, the "high score states" and the "low score states" have similar values. When we look at firm age, we do not see any significant difference between the two groups. None of the firm age variables is significantly different across high- and low-score states. With regard to firm size, we are seeing that there are fewer firms with a single employee in the high-score states (i.e., $49.78 \%$ ) compared to the low-score states (i.e., 56.12\%). This difference is significant $(\mathrm{p}=0.0010)$. Also, we are seeing that there are more firms with 2-20 employees in the high-score states (i.e., 48.45\%) compared to the low-score states (i.e., 42.67\%). This difference is also statistically significant $(\mathrm{p}=0.0038)$. We do not see any difference between the two groups in terms of the other firm size groups. The two groups are similar concerning the percentage of larger firms.

Table 3. The Impact of "Employment Regulations" on Firm Characteristics

\begin{tabular}{|c|c|c|c|c|c|}
\hline \multirow[b]{2}{*}{ Variable } & \multicolumn{2}{|c|}{ High-Score } & \multicolumn{2}{|c|}{ Low-Score } & \multirow{2}{*}{$\frac{\text { Mann-W. }}{\text { p-value }}$} \\
\hline & Mean & Med. & Mean & Med. & \\
\hline \multicolumn{6}{|c|}{ Panel A. Operational Area } \\
\hline Operstates1 & 64.29 & 67.92 & 65.24 & 66.67 & 0.4378 \\
\hline Operstates2-5 & 27.61 & 25.77 & 27.66 & 26.71 & 0.4792 \\
\hline Operstates $>5$ & 8.11 & 8.45 & 7.10 & 7.26 & 0.2169 \\
\hline Mostlocal & 86.85 & 87.48 & 88.44 & 88.49 & 0.4021 \\
\hline \multicolumn{6}{|l|}{ Panel B. Firm Age } \\
\hline Ageofbus $<1$ & 5.86 & 5.56 & 6.45 & 6.08 & 0.2830 \\
\hline Ageofbus1-2 & 17.29 & 17.29 & 17.34 & 15.97 & 0.3722 \\
\hline Ageofbus3-4 & 17.68 & 18.18 & 18.43 & 18.86 & 0.1841 \\
\hline Ageofbus $>4$ & 59.17 & 57.24 & 57.78 & 57.50 & 0.4948 \\
\hline \multicolumn{6}{|l|}{ Panel C. Firm Size } \\
\hline Employees1 & 49.78 & 50.68 & 56.12 & 55.00 & $* * * 0.0010$ \\
\hline Employees2-20 & 48.45 & 47.46 & 42.67 & 44.17 & $* * * 0.0038$ \\
\hline Employees21-50 & 1.03 & 0.82 & 0.72 & 0.57 & 0.2138 \\
\hline Employees51-100 & 0.23 & 0.00 & 0.19 & 0.00 & 0.3730 \\
\hline Employees $>100$ & 0.51 & 0.00 & 0.30 & 0.00 & 0.2476 \\
\hline \multicolumn{6}{|c|}{ Panel D. Firm Industry } \\
\hline Business & 6.40 & 6.18 & 4.81 & 5.17 & $* 0.0720$ \\
\hline Care & 3.88 & 3.80 & 5.05 & 4.42 & 0.1483 \\
\hline Events & 22.38 & 20.80 & 21.55 & 21.00 & 0.4844 \\
\hline Instruction & 6.71 & 6.14 & 7.34 & 8.06 & 0.1806 \\
\hline Vehicle & 2.32 & 2.34 & 2.61 & 2.60 & 0.2870 \\
\hline Health & 11.64 & 11.02 & 14.18 & 13.08 & $* * 0.0124$ \\
\hline Home & 35.85 & 36.50 & 34.24 & 35.00 & 0.1367 \\
\hline Technology & 10.40 & 9.52 & 9.10 & 8.87 & 0.3240 \\
\hline Writing & 0.42 & 0.00 & 1.10 & 0.98 & $* * * 0.0032$ \\
\hline
\end{tabular}

Source: Compiled by the author

With regard to firm industry, we are seeing that there is no significant difference between the two groups except for the "Business", "Health", and "Writing" industries. There are significantly more firms in the highscore states that are in the "Business" industry when compared to the low-score states. While $6.40 \%$ of the firms in the high-score states are in this industry, the corresponding percentage is $4.81 \%$ in the low-score states. This difference is statistically significant $(\mathrm{p}=0.0720)$. On the other hand, there are significantly fewer firms in the high-score states that are in the "Health" and "Writing" industries when compared to the low-score states. While $11.64 \%$ of the firms in the high-score states are in this industry, the corresponding percentage is $14.18 \%$ in the low-score states.

This difference is statistically significant $(\mathrm{p}=0.0124)$. While $0.42 \%$ of the firms in the high-score states are in this industry, the corresponding percentage is $1.10 \%$ in the low-score states. The p-value of the difference is 0.0032. Table 4 examines the firm characteristics across the high- and low- "tax code score" states. We are seeing that none of the operational area variables or the local sales variable (i.e., "most local") is significantly different between the two groups. In other words, the "high score states" and the "low score states" have similar values. When we look at firm age, again we are not seeing any significant difference between the two groups. None of the firm age variables is significantly different across high- and low-score states. 
Table 4. The Impact of "Tax Code" on Firm Characteristics

\begin{tabular}{|c|c|c|c|c|c|}
\hline \multirow[b]{2}{*}{ Variable } & \multicolumn{2}{|c|}{ High-Score } & \multicolumn{2}{|c|}{ Low-Score } & \multirow{2}{*}{$\frac{\text { Mann-W. }}{\text { p-value }}$} \\
\hline & Mean & Med. & Mean & Med. & \\
\hline \multicolumn{6}{|c|}{ Panel A. Operational Area } \\
\hline Operstates1 & 65.72 & 68.49 & 63.43 & 66.31 & 0.2214 \\
\hline Operstates2-5 & 26.26 & 23.92 & 29.58 & 27.50 & 0.1704 \\
\hline Operstates $>5$ & 8.02 & 7.82 & 6.99 & 7.53 & 0.2374 \\
\hline Mostlocal & 87.23 & 87.87 & 88.28 & 88.49 & 0.4631 \\
\hline \multicolumn{6}{|l|}{ Panel B. Firm Age } \\
\hline Ageofbus $<1$ & 6.28 & 5.89 & 5.99 & 6.02 & 0.3457 \\
\hline Ageofbus1-2 & 17.37 & 17.29 & 17.24 & 15.71 & 0.2499 \\
\hline Ageofbus3-4 & 18.20 & 18.32 & 17.87 & 18.86 & 0.4059 \\
\hline Ageofbus $>4$ & 58.15 & 55.79 & 58.90 & 58.14 & 0.1573 \\
\hline \multicolumn{6}{|l|}{ Panel C. Firm Size } \\
\hline Employees1 & 50.73 & 51.12 & 56.26 & 55.00 & $* * * 0.0021$ \\
\hline Employees2-20 & 47.74 & 46.73 & 42.31 & 43.75 & $* * * 0.0028$ \\
\hline Employees21-50 & 0.85 & 0.70 & 0.91 & 0.83 & 0.3977 \\
\hline Employees51-100 & 0.22 & 0.00 & 0.20 & 0.00 & 0.3082 \\
\hline Employees $>100$ & 0.46 & 0.00 & 0.32 & 0.00 & 0.2889 \\
\hline \multicolumn{6}{|c|}{ Panel D. Firm Industry } \\
\hline Business & 6.32 & 6.03 & 4.56 & 4.93 & $* * 0.0391$ \\
\hline Care & 4.13 & 3.86 & 4.97 & 4.28 & 0.4213 \\
\hline Events & 21.49 & 20.80 & 22.61 & 22.46 & 0.4526 \\
\hline Instruction & 6.83 & 6.25 & 7.33 & 7.96 & 0.2541 \\
\hline Vehicle & 2.73 & 2.84 & 2.10 & 2.35 & 0.1298 \\
\hline Health & 12.24 & 11.44 & 13.93 & 13.08 & $* 0.0657$ \\
\hline Home & 36.14 & 36.26 & 33.46 & 34.78 & $* 0.0592$ \\
\hline Technology & 9.69 & 9.07 & 9.80 & 9.52 & 0.2670 \\
\hline Writing & 0.44 & 0.00 & 1.23 & 1.06 & $* * * 0.0027$ \\
\hline
\end{tabular}

Source: Compiled by the author

With regard to firm size, we are seeing that there are fewer firms with a single employee in the high-score states (i.e., 50.73\%) compared to the low-score states (i.e., 56.26\%). This difference is significant ( $\mathrm{p}=0.0021)$. Also, we are seeing that there are more firms with 2-20 employees in the high-score states (i.e., 47.74\%) compared to the low-score states (i.e., 42.31\%). This difference is also statistically significant $(p=0.0028)$. We do not see any difference between the two groups in terms of the other firm size groups. The two groups are similar with respect to the percentage of larger firms. With regard to firm industry, we are seeing that there is no significant difference between the two groups except for the "Business", "Health", "Home", and "Writing" industries. There are significantly more firms in the high-score states that are in the "Business" and "Home" industries when compared to the low-score states. On the other hand, there are significantly fewer firms in the high-score states that are in the "Health" and "Writing" industries when compared to the low-score states.

Table 5 compares the firm characteristics across the high- and low- "licensing regulations score" states. We are seeing that none of the operational area variables or the local sales variable (i.e., "most local") is significantly different between the two groups. In other words, the "high score states" and the "low score states" have similar values. When we look at firm age, again we are not seeing any significant difference between the two groups. None of the firm age variables is significantly different across high- and low-score states. With regard to firm size, we are seeing that there are fewer firms with a single employee in the highscore states (i.e., 50.95\%) compared to the low-score states (i.e., 55.01\%). This difference is significant $(\mathrm{p}=0.0184)$. Also, we are seeing that there are more firms with 2-20 employees in the high-score states (i.e., $47.30 \%)$ compared to the low-score states (i.e., 43.76\%). This difference is also statistically significant $(\mathrm{p}=0.0543)$. We do not see any difference between the two groups in terms of the other firm size groups. The two groups are similar with respect to the percentage of larger firms.

With regard to firm industry, we are seeing that there is no significant difference between the two groups except for the "Business", "Vehicle", and "Writing" industries. There are significantly more firms in the highscore states that are in the "Business" industry when compared to the low-score states. On the other hand, there are significantly fewer firms in the high-score states that are in the "Vehicle" and "Writing" industries when compared to the low-score states. 
Table 5. The Impact of "Licensing Regulations" on Firm Characteristics

\begin{tabular}{|c|c|c|c|c|c|}
\hline \multirow[b]{2}{*}{ Variable } & \multicolumn{2}{|c|}{ High-Score } & \multicolumn{2}{|c|}{ Low-Score } & \multirow{2}{*}{$\frac{\text { Mann-W. }}{\text { p-value }}$} \\
\hline & Mean & Med. & Mean & Med. & \\
\hline \multicolumn{6}{|c|}{ Panel A. Operational Area } \\
\hline Operstates1 & 65.69 & 68.49 & 63.91 & 66.31 & 0.2830 \\
\hline Operstates2-5 & 26.40 & 23.92 & 28.81 & 27.50 & 0.2406 \\
\hline Operstates $>5$ & 7.91 & 7.82 & 7.28 & 7.53 & 0.3382 \\
\hline Mostlocal & 87.17 & 88.20 & 88.14 & 88.24 & 0.3430 \\
\hline \multicolumn{6}{|l|}{ Panel B. Firm Age } \\
\hline Ageofbus $<1$ & 6.09 & 5.98 & 6.23 & 6.02 & 0.4792 \\
\hline Ageofbus1-2 & 17.19 & 17.29 & 17.43 & 15.97 & 0.4327 \\
\hline Ageofbus3-4 & 17.65 & 18.18 & 18.46 & 18.86 & 0.1876 \\
\hline Ageofbus $>4$ & 59.07 & 56.65 & 57.88 & 57.61 & 0.3971 \\
\hline \multicolumn{6}{|l|}{ Panel C. Firm Size } \\
\hline Employees1 & 50.95 & 51.12 & 55.01 & 54.31 & $* * 0.0184$ \\
\hline Employees2-20 & 47.30 & 46.38 & 43.76 & 44.38 & $* 0.0543$ \\
\hline Employees21-50 & 0.94 & 0.82 & 0.81 & 0.57 & 0.3433 \\
\hline Employees51-100 & 0.23 & 0.00 & 0.19 & 0.00 & 0.3730 \\
\hline Employees $>100$ & 0.57 & 0.00 & 0.24 & 0.00 & 0.5000 \\
\hline \multicolumn{6}{|c|}{ Panel D. Firm Industry } \\
\hline Business & 6.43 & 6.65 & 4.79 & 5.31 & $* 0.0853$ \\
\hline Care & 3.97 & 3.86 & 4.96 & 4.28 & 0.3381 \\
\hline Events & 22.12 & 21.03 & 21.80 & 20.71 & 0.2447 \\
\hline Instruction & 6.64 & 6.14 & 7.41 & 8.06 & 0.1424 \\
\hline Vehicle & 2.12 & 1.87 & 2.81 & 3.08 & $* 0.0934$ \\
\hline Health & 12.56 & 11.54 & 13.30 & 12.86 & 0.2020 \\
\hline Home & 35.88 & 36.45 & 34.22 & 35.00 & 0.1424 \\
\hline Technology & 9.68 & 9.07 & 9.78 & 9.52 & 0.2530 \\
\hline Writing & 0.60 & 0.00 & 0.93 & 0.83 & $* * 0.0309$ \\
\hline
\end{tabular}

Source: Compiled by the author

Table 6 compares the firm characteristics across the high- and low- "environmental regulations score" states. We are seeing that none of the operational area variables or the local sales variable (i.e., "mostlocal") is significantly different between the two groups. In other words, the "high score states" and the "low score states" have similar values. When we look at firm age, again we are not seeing any significant difference between the two groups. None of the firm age variables is significantly different across high- and low-score states. With regard to firm size, we are seeing that there are fewer firms with a single employee in the highscore states (i.e., 51.09\%) compared to the low-score states (i.e., 55.50\%). This difference is significant $(\mathrm{p}=0.0073)$. Also, we are seeing that there are more firms with 2-20 employees in the high-score states (i.e., $47.42 \%)$ compared to the low-score states (i.e., 43.02\%). This difference is also statistically significant $(\mathrm{p}=0.0132)$. This time, we are also seeing that there are fewer firms with 51-100 employees in the high-score states (i.e., $0.13 \%$ ) compared to the low-score states (i.e., $0.32 \%$ ). This difference is also statistically significant $(\mathrm{p}=0.0087)$.

Table 6. The Impact of "Environmental Regulations" on Firm Characteristics

\begin{tabular}{|c|c|c|c|c|c|}
\hline \multirow[b]{2}{*}{ Variable } & \multicolumn{2}{|c|}{ High-Score } & \multicolumn{2}{|c|}{ Low-Score } & \multirow{2}{*}{$\begin{array}{c}\text { Mann-W. } \\
\text { p-value }\end{array}$} \\
\hline & Mean & Med. & Mean & Med. & \\
\hline \multicolumn{6}{|c|}{ Panel A. Operational Area } \\
\hline Operstates1 & 64.32 & 67.35 & 65.36 & 66.87 & 0.3664 \\
\hline Operstates2-5 & 27.72 & 25.45 & 27.53 & 27.11 & 0.5000 \\
\hline Operstates $>5$ & 7.96 & 8.24 & 7.12 & 7.40 & 0.3468 \\
\hline Mostlocal & 87.39 & 88.89 & 88.02 & 87.23 & 0.2473 \\
\hline \multicolumn{6}{|l|}{ Panel B. Firm Age } \\
\hline Ageofbus $<1$ & 6.19 & 5.66 & 6.13 & 6.14 & 0.4895 \\
\hline Ageofbus1-2 & 17.30 & 16.98 & 17.34 & 15.90 & 0.4116 \\
\hline Ageofbus3-4 & 18.07 & 18.46 & 18.06 & 18.87 & 0.3276 \\
\hline Ageofbus $>4$ & 58.44 & 57.14 & 58.48 & 58.41 & 0.2270 \\
\hline \multicolumn{6}{|l|}{ Panel C. Firm Size } \\
\hline Employees1 & 51.09 & 50.94 & 55.50 & 54.94 & $* * * 0.0073$ \\
\hline Employees2-20 & 47.42 & 47.84 & 43.02 & 44.28 & $* * 0.0132$ \\
\hline Employees21-50 & 0.90 & 0.62 & 0.84 & 0.81 & 0.4408 \\
\hline Employees51-100 & 0.13 & 0.00 & 0.32 & 0.21 & $* * * 0.0087$ \\
\hline Employees $>100$ & 0.46 & 0.00 & 0.33 & 0.13 & 0.1585 \\
\hline
\end{tabular}


Table 6 (cont.). The Impact of "Environmental Regulations" on Firm Characteristics

\begin{tabular}{|l|c|c|c|c|c|}
\hline Panel D. Firm Industry & 6.36 & 5.88 & 4.60 & 4.96 & $* * 0.0236$ \\
\hline Business & 3.75 & 3.77 & 5.41 & 4.45 & $* 0.0779$ \\
\hline Care & 22.08 & 20.63 & 21.80 & 22.67 & 0.3468 \\
\hline Events & 6.85 & 6.13 & 7.28 & 8.31 & 0.1930 \\
\hline Instruction & 2.44 & 2.78 & 2.51 & 2.55 & 0.5000 \\
\hline Vehicle & 12.45 & 11.64 & 13.57 & 12.77 & 0.1930 \\
\hline Health & 35.56 & 36.21 & 34.35 & 34.89 & 0.2153 \\
\hline Home & 10.04 & 9.52 & 9.34 & 9.20 & 0.4425 \\
\hline Technology & 0.47 & 0.00 & 1.14 & 0.94 & $* * * 0.0031$ \\
\hline Writing & & & & \\
\hline
\end{tabular}

Source: Compiled by the author

With regard to firm industry, we are seeing that there is no significant difference between the two groups except for the "Business", "Care", and "Writing" industries. There are significantly more firms in the highscore states that are in the "Business" industry when compared to the low-score states. On the other hand, there are significantly fewer firms in the high-score states that are in the "Care" and "Writing" industries when compared to the low-score states. Table 7 compares the firm characteristics across the high- and low- "zoning regulations score" states. We are seeing that none of the operational area variables or the local sales variable (i.e., "most local") is significantly different between the two groups.

Table 7. The Impact of "Zoning Regulations" on Firm Characteristics

\begin{tabular}{|c|c|c|c|c|c|}
\hline \multirow[b]{2}{*}{ Variable } & \multicolumn{2}{|c|}{ High-Score } & \multicolumn{2}{|c|}{ Low-Score } & \multirow{2}{*}{$\begin{array}{c}\text { Mann-W. } \\
\text { p-value }\end{array}$} \\
\hline & Mean & Med. & Mean & Med. & \\
\hline \multicolumn{6}{|c|}{ Panel A. Operational Area } \\
\hline Operstates1 & 63.78 & 67.92 & 65.72 & 67.02 & 0.3382 \\
\hline Operstates $2-5$ & 28.33 & 25.77 & 26.97 & 26.71 & 0.4174 \\
\hline Operstates $>5$ & 7.89 & 7.31 & 7.31 & 8.07 & 0.4688 \\
\hline Mostlocal & 86.84 & 88.20 & 88.45 & 88.24 & 0.4948 \\
\hline \multicolumn{6}{|l|}{ Panel B. Firm Age } \\
\hline Ageofbus $<1$ & 5.49 & 5.56 & 6.81 & 6.67 & $* 0.0875$ \\
\hline Ageofbus1-2 & 16.95 & 17.29 & 17.66 & 15.91 & 0.4636 \\
\hline Ageofbus3-4 & 17.76 & 17.36 & 18.35 & 18.99 & 0.1229 \\
\hline Ageofbus $>4$ & 59.80 & 58.41 & 57.19 & 57.14 & 0.2572 \\
\hline \multicolumn{6}{|l|}{ Panel C. Firm Size } \\
\hline Employees1 & 51.91 & 51.69 & 54.09 & 53.65 & 0.1423 \\
\hline Employees2-20 & 46.55 & 45.26 & 44.48 & 44.38 & 0.1705 \\
\hline Employees21-50 & 0.86 & 0.50 & 0.89 & 0.83 & 0.3684 \\
\hline Employees51-100 & 0.17 & 0.00 & 0.25 & 0.00 & 0.1300 \\
\hline Employees $>100$ & 0.51 & 0.00 & 0.30 & 0.00 & 0.2337 \\
\hline \multicolumn{6}{|c|}{ Panel D. Firm Industry } \\
\hline Business & 6.53 & 6.46 & 4.69 & 5.00 & $* * 0.0252$ \\
\hline Care & 3.93 & 3.80 & 5.00 & 4.42 & 0.1910 \\
\hline Events & 23.48 & 21.26 & 20.50 & 20.45 & $* 0.0757$ \\
\hline Instruction & 6.85 & 6.14 & 7.22 & 7.96 & 0.2406 \\
\hline Vehicle & 2.50 & 2.80 & 2.44 & 2.50 & 0.4532 \\
\hline Health & 12.49 & 11.54 & 13.37 & 12.86 & 0.1876 \\
\hline Home & 34.84 & 35.45 & 35.21 & 35.42 & 0.4378 \\
\hline Technology & 8.96 & 8.55 & 10.47 & 10.73 & $* * 0.0438$ \\
\hline Writing & 0.42 & 0.00 & 1.10 & 0.98 & $* * * 0.0039$ \\
\hline
\end{tabular}

Source: Compiled by the author

When we look at firm age, we find that the two groups are significantly different only in terms of the percentage of firms that is less than one year old. Few firms are less than one year old in the high-score states (i.e., 5.49\%) compared to the low-score states (i.e., 6.81\%). This difference is significant $(\mathrm{p}=0.0875)$. None of the other firm age variables is significantly different across high- and low-score states. Regarding firm size, we see that none of the firm size variables is significantly different between the two groups. With regard to firm industry, we see that there is no significant difference between the two groups except for the "Business", "Events", "Technology", and "Writing" industries. There are significantly more firms in the high-score states that are in the "Business" and "Events" industries when compared to the low-score states. On the other hand, there are significantly fewer firms in the high-score states that are in the "Technology" and "Writing" industries when compared to the low-score states. 


\section{Conclusion}

Most of the previous studies show that regulations have a negative impact on entrepreneurial activity. Regulations increase the costs of entry and compliance costs; hence they affect a firm's decision to operate in that country/state. This impact is more pronounced for smaller firms (i.e., we call it the "size-effect"). In this study, we focus on U.S. states and examine whether regulations in a state affect the characteristics of firms operating in that state. Our first contribution is to determine whether different types of regulations in a U.S. state help attract or deter smaller firms from operating in that state (i.e., size-effect). We investigate whether "health and safety regulations", "employment regulations", "tax code", "licensing regulations", "environmental regulations", or "zoning regulations" in a state deter smaller firms from operating in that state. Our second contribution is to examine whether different types of regulations in a U.S. state affect other firm characteristics like firm age, firm industry, and operational area. What kind of firms are attracted to states with more favorable employment regulations? What kind of firms are attracted to states with a more favorable tax code? What kind of firms are attracted to states with more favorable licensing regulations? In other words, do more favorable regulations in certain areas help attract younger or older firms, or firms in certain industries, or larger firms operating in different states? Therefore, besides the size-effect, in this study, we also examine the relationship between regulations and other firm characteristics like firm age, industry, and operational area.

Our results show that there are significant differences between the high-score states and the low-score states. We find that "health and safety regulations", "employment regulations", "tax code", "licensing regulations", and "environmental regulations" in a state affect firm size and industry but do not affect the operational area and firm age. Therefore, we can say that attracting larger firms or firms from certain sectors depends upon the quality of regulations in the eyes of the business owners. In the states with high scores in these areas, there are fewer single-employee firms and more than 2-20 employee firms compared to the other states. We also find that in the states with a high score in "environmental regulations", there are fewer firms with 51 to 100 employees when compared to the other states.

On the other hand, "zoning regulations" affect firm age and industry, but not operational area and firm size. Few firms were established less than a year ago in the states with high scores in "zoning regulations". We can say that, in the states with high scores in regulations, generally, there are more firms in the "Business" industry and fewer firms in the "Writing" industry.

To conclude, our results show that there is a size-effect for "health and safety regulations", "employment regulations", "tax code", "licensing regulations", and "environmental regulations". There is a no-size effect (i.e., certain size groups are not more or less common in the states with above-average zoning regulations). There are more firms with 2-20 employees in the states where "health and safety regulations", "employment regulations", "tax code", "licensing regulations", and "environmental regulations" are more favorable. Interestingly, there are fewer single-employee firms in the states where these regulations are more favorable. Therefore, we can say that the decision-making process (i.e., starting and continuing operations in a state) for a single-employee firm is different from the decision-making process for other small firms. Our results also show that there is no age-effect or an operational area-effect about "health and safety regulations", "employment regulations", "tax code", "licensing regulations", and "environmental regulations". In other words, in the states where these regulations are more favorable, we do not find younger or older firms to be more common or firms with a larger or smaller operational area to be more common. Interestingly, we find that in the states with more favorable zoning regulations, there are fewer newly founded (age less than one) firms.

With regard to industry-effect, we find that different types of regulations attract firms to other industries. Therefore, there is evidence of an industry-effect. Better regulations in certain areas attract more firms in certain sectors. Policymakers should consider the findings in this study when devising their strategies to attract small businesses to their states. If they want to attract smaller firms, then they need to improve "health and safety regulations", "employment regulations", "tax code", "licensing regulations", and "environmental regulations". If they want to attract younger firms or firms operating in larger areas, regulations do not seem to matter. If they want to attract firms into certain industries, they need to improve certain regulations, as shown in this study. We believe that these findings are important. Entrepreneurial activity in different countries may react differently to different types of regulations, but our results can be taken as a base for country-specific studies that will be done in the future.

Funding. There is no funding for this research. 


\section{References}

1. Acs, Z.J., Braunerhjelm, P., Audretsch, D.B., Carlsson, B. (2009). The knowledge spillover theory of entrepreneurship. Small business economics, 32(1), 15-30. [Google Scholar]

2. Acs, Z.J., Szerb, L. (2007). Entrepreneurship, economic growth and public policy. Small business economics, 28(2-3), 109-122. [Google Scholar]

3. Aidis, R., Estrin, S., Mickiewicz, T. (2008). Institutions and entrepreneurship development in Russia: A comparative perspective. Journal of Business Venturing, 23(6), 656-672. [Google Scholar]

4. Aidis, R., Welter, F., Smallbone, D., Isakova, N. (2007). Female entrepreneurship in transition economies: the case of Lithuania and Ukraine. Feminist Economics, 13(2), 157-183. [Google Scholar]

5. Bailey, J.B., Thomas, D.W. (2017). Regulating away competition: The effect of regulation on entrepreneurship and employment. Journal of Regulatory Economics, 52(3), 237-254. [Google Scholar]

6. Birnbaum, P.H. (1984). The Choice of Strategic Alternatives under Increasing Regulation in High Technology Companies. The Academy of Management Journal, 27(3), 489-510. [Google Scholar] [CrossRef]

7. Bitzenis, A., Nito, E. (2005). Obstacles to entrepreneurship in a transition business environment: the case of Albania. Journal of Small Business and Enterprise Development, 12(4), 564-578. [Google Scholar]

8. Bjørnskov, C., Foss, N.J. (2008). Economic freedom and entrepreneurial activity: Some cross-country evidence. Public Choice, 134(3), 307-328. [Google Scholar]

9. Branstetter, L., Lima, F., Taylor, L.J., Venâncio, A. (2014). Do entry regulations deter entrepreneurship and job creation? Evidence from recent reforms in Portugal. The Economic Journal, 124(577), 805-832. [Google Scholar]

10.Brock, W.A., Evans D.S. (1989). Small business economics. Small business economics, 1(1), 7-20. [Google Scholar]

11.Calcagno, P.T., Sobel, R.S. (2014). Regulatory costs on entrepreneurship and establishment employment size. Small Business Economics, 42(3), 541-559. [Google Scholar]

12.Dean, T.J., Brown, R.L. (1995). Pollution regulation as a barrier to new firm entry: Initial evidence and implications for future research," Academy of Management Journal, 38(1), 288-303. [Google Scholar]

13.Djankov, S., Porta, R. La, Lopez-de-Silanes, F., Shleifer, A. (2002). The regulation of entry. The quarterly Journal of economics, 117(1), 1-37. [Google Scholar]

14.Dreher, A., Gassebner, M. (2013). Greasing the wheels? The impact of regulations and corruption on firm entry. Public Choice, 155(3-4), 413-432. [Google Scholar]

15.García-Posada, M., Mora-Sanguinetti, J.S. (2015). Entrepreneurship and enforcement institutions: Disaggregated evidence for Spain. European Journal of Law and Economics, 1-26. [Google Scholar]

16.Gartner, W.B., Shane, S.A. (2014). Measuring entrepreneurship over time. Regional Studies, 48(6), 1071-1089. [Google Scholar]

17.Ghani, E., Kerr, W.R., O'Connell, S. (2014). Spatial determinants of entrepreneurship in India. Regional Studies, 48(6), 1071-1089. [Google Scholar]

18.Helland, E., Matsuno, M. (2003). Pollution abatement as a barrier to entry. Journal of Regulatory Economics, 24(2), 243-259. [Google Scholar]

19.Klapper, L., Laeven, L., Rajan, R. (2006). Entry regulation as a barrier to entrepreneurship. Journal of Financial Economics, 82(3), 591-629. [Google Scholar]

20.Manolova, T.S., Eunni, R.V., Gyoshev, B.S. (2008). Institutional environments for entrepreneurship: Evidence from emerging economies in Eastern Europe. Entrepreneurship Theory and Practice, 32(1), 203-218. [Google Scholar] [CrossRef]

21.Nawaser, K., Khaksar, S.M.S., Shaksian, F., Jahanshahi, A.A. (2011). Motivational and legal barriers of entrepreneurship development. International Journal of Business and Management, 6(11), 112. [Google $\underline{\text { Scholarl }}$

22.Nyström, K. (2008). The institutions of economic freedom and entrepreneurship: evidence from panel data. Public Choice, 136(3-4), 269-282. [Google Scholar]

23.Ovaska, T., Sobel, R.S. (2005). Entrepreneurship in post-socialist economies. Journal of Private Enterprise, 21(1), 8-28. [Google Scholar]

24.Parker, S.C. (2007). Law and the Economics of Entrepreneurship. Comparative Labor Law \& Policy Journal, 28(4). [Google Scholar]

25.Pashigian, B.P. (1984). The effect of environmental regulation on optimal plant size and factor shares. The Journal of Law and Economics, 27(1), 1-28. [Google Scholar]

26.Peltzman, S. (1976). Toward a more general theory of regulation. The Journal of Law and Economics, 19(2), 211-240. [Google Scholar] 
27.Pigou, A.C. (2013). The economics of welfare. Palgrave Macmillan. [Google Scholar]

28.Smallbone, D., Welter, F., Voytovich, A., Egorov, I. (2010). Government and entrepreneurship in transition economies: the case of small firms in business services in Ukraine. The service industries Journal, 30(5), 655-670. [Google Scholar] [CrossRef]

29.Sobel, R.S., Clark, J.R., Lee, D. R. (2007). Freedom, barriers to entry, entrepreneurship, and economic progress. The Review of Austrian Economics, 20(4), 221-236. [Google Scholar]

30.Stephan, U., Uhlaner, L.M. (2010). Performance-based vs socially supportive culture: A cross-national study of descriptive norms and entrepreneurship. Journal of International Business Studies, 41(8), 13471364. [Google Scholar]

31.Stigler, G.J. (2021). The theory of economic regulation, Routledge. Available at: [Link]

32.Thomas, L.G. (1990). Regulation and firm size: FDA impacts on innovation. The RAND Journal of Economics, 497-517. [Google Scholar]

33.Tullock, G. (1967). The welfare costs of tariffs, monopolies, and theft. Economic Inquiry, 5(3), 224-232. [Google Scholar]

34.Valdez, M.E., Richardson, J. (2013). Institutional Determinants of Macro-Level Entrepreneurship. Entrepreneurship Theory and Practice, 37(5), 1149-1175. [Google Scholar]

35.Van S.A., Storey, D.J., Thurik, A. R. (2007). The effect of business regulations on nascent and young business entrepreneurship. Small Business Economics, 28(2-3), 171-186. [Google Scholar]

36.Wennekers, S., Thurik, R. (1999). Linking entrepreneurship and economic growth. Small business economics, 13(1), 27-56. [Google Scholar] 